\title{
Hubungan Rasa Percaya Diri, Kelentukan Togok, Dan Koordinasi Mata Kepala Dengan Kemampuan Menyundul Bola Posisi Berdiri
}

\author{
${ }^{1}$ Domi Bustomi $\bowtie,{ }^{2}$ Adli Azhari \\ 12Universitas Islam 45 Bekasi \\ 1dbustomi01@gmail.com, 2adliazhari50@gmail.com
}

\begin{abstract}
ABSTRAK
Penelitian ini bertujuan untuk mengetahui seberapa besarnya hubungan rasa percaya diri, kelentukan togok dan koordinasi mata-kepala dengan Kemampuan Menyundul Bola Posisi Berdiri. Penelitian ini dilaksanakan terhadap atlet sepakbola Klub Andeci Kab. Karawang, dengan menggunakan metode korelasional, yang dalam pengambilan sampelnya berjumlah 20 orang menggunakan metode sampling jenuh (sensus). Pengumpulan data dilakukan dengan tes Kemampuan Menyundul Bola Posisi Berdiri, kuesioner rasa percaya diri, flexiometer untuk tes kelentukan togok dan tes koordinasi mata-kepala. Hasil penelitian menunjukkan: (1) terdapat hubungan yang signifikan antara percaya diri dengan Kemampuan Menyundul Bola Posisi Berdiri dengan rxiy= 0.732 dengan kontribusi sebesar $54.17 \%$, (2) terdapat hubungan yang signiifikan antara kelentukan togok dengan Kemampuan Menyundul Bola Posisi Berdiri dengan rx2y= 0.84 dengan kontribusi sebesar $77.44 \%$, (3) terdapat hubungan yang sangat signifikan antara koordinasi mata-kepala dengan Kemampuan Menyundul Bola Posisi Berdiri dengan $\mathrm{rx} 3 \mathrm{y}=0.764$ dengan kontribusi sebesar $58.83 \%$, dan (4) terdapat hubungan yang signifikan antara rasa percaya diri, kelentukan togok dan koordinasi mata-kepala dengan Kemampuan Menyundul Bola Posisi Berdiri dengan $\mathrm{rx}_{123 \mathrm{y}}=0.87$ dengan kontribusi sebesar $79.21 \%$.
\end{abstract}

Kata Kunci: Percaya diri, Kelentukan Togok, Koordinasi Mata-Kepala, dan Menyundul Bola

\section{ABSTRAC}

This study aims to determine how much the relationship of self-confidence, the shape of the stick and eye-head coordination with the Ability to Head Standing Ball Position. This research was conducted on the athletes of the Club Andeci Junior football using the correlational method, which in the sampling amounted to 20 people using the saturated sampling method (census). Data collection was carried out by the Standing Position Ball Ability test, self-confidence questionnaire, flexiometer for bench test and eye-head coordination test. The results showed: (1) there was a significant relationship between confidence and Ability to Lead a Standing Ball with rx1y $=0.732$ with a contribution of $54.17 \%$, (2) there was a significant relationship between the shape of the ball with Stand Position Ball Ability with rx2y = 0.84 with a contribution of $77.44 \%$, (3) there is a very significant relationship between eye-head coordination with the Ability to Head a Standing Ball with $\mathrm{rx3y}=0.764$ with a contribution of $58.83 \%$, and (4) there is a significant relationship between self-confidence and eye-head coordination with Stand Position Ball Ability with rx123y $=0.87$ with a contribution of $79.21 \%$.

Keyword: Confidence, Togok flexibility, Head eye coordination,Ball heading

Alamat Korespondensi: Universitas Islam 45 Bekasi

$\bowtie$ Email: dbustomi01@gmail.com

(C) 2020 STKIP Pasundan

ISSN 2721-5660 (Cetak)

ISSN 2722-1202 (Online) 


\section{PENDAHULUAN}

Sepakbola adalah salah satu olahraga yang telah populer dan disukai banyak masyarakat. Permainan ini sudah berkembang menjadi olahraga yang sangat digemari oleh semua kalangan masyarakat. Dengan berbagai latar belakang serta tujuan yang berbeda serta makin menjamurnya Klub-klub sepakbola maupun sekolah sepakbola (SSB), ini membuktikan bahwa sepakbola merupakan cabang olahraga yang sangat populer di masyarakat kita, sehingga tidak jarang kita dengar bahwa sepakbola merupakan olahraga yang bermasyarakat. Disamping itu, sepakbola juga dipercaya selain bisa belajar untuk menumbuhkan dan mengembangkan aspek kognitif, juga aspek afektif seperti sikap sportif, tanggung jawab, kerjasama, menghargai dapat dibentuk melalui olahraga ini (Valentino \& Iskandar, 2020).

Kabupaten Karawang memiliki Klub yang banyak salah satu diantaranya adalah Klub sepakbola ANDECI Junior, Disamping itu ANDECI Junior juga sudah banyak memproduksi pemain-pemain handal untuk Kabupaten Karawang. Hal ini tidak lepas dari pembinaan pemain sejak dini yang dilakukan oleh Klub ANDECI Junior. Persatuan sepakbola ANDECI Junior merupakan salah satu Klub yang sudah melakukan proses latihan dengan baik, dimana mereka mempunyai jadwal latihan yang rutin yaitu melakukan latihan tiga kali dalam seminggu, yaitu; Selasa, Kamis dan Sabtu pukul 14.00 WIB dan dibina oleh staf pelatih yang berstatus A Lisence, B Lisence, C Lisence dan D Lisence serta memiliki lapangan yang cukup bagus dipinggir jalan raya dan disamping SMP Negeri 2 Lemahabang-Karawang. Dalam upaya membina prestasi sepakbola, belum cukup dengan pelatih yang berlisence A ataupun B dengan lapangan yang bagus, akan tetapi juga harus didukung oleh kondisi Fisik, teknik, taktik dan mental yang baik bagi para pemain tersebut.

Berdasarkan hasil wawancara penulis dengan pelatih Klub sepakbola ANDECI Junior Karawang, Coach Heriyana pada tanggal 15 September 2019, dikatakan bahwa pemain sepakbola Klub ANDECI Junior masih banyak kelemahan-kelemahannya terutama dari segi teknik menyerang sering mengalami kegagalan, hal ini terbukti ketika bertanding uji coba dengan VOKER Karawang, penyusunan serangan dari lini kelini sudah bagus, operan-operan sudah baik, tapi sering di temukan saat pemain berusaha untuk menyundul bola sering mengalami kegagalan, bola jauh dari target sehingga dengan mudahnya dikusai kembali oleh lawan, padahal menyundul bola satu hal yang penting dalam melakukan operan atau upaya menciptakan gol.

Menyundul bola merupakan salah satu teknik yang terpenting dalam permainan sepakbola mutlak harus dikuasai oleh setiap pemain. Sucipto, dkk (2000) menyatakan bahwa menyundul bola adalah memainkan bola dengan kepala, dimana tujuannya adalah untuk mengumpan, mencetak gol, dan mematahkan serangan lawan/membuang bola. Untuk memudahkan dalam menyundul bola yang baik dan efisien banyak faktor yang mempengaruhinya, diantaranya teknik, 
mental dan kondisi fisik. Komponen-komponen kondisi fisik yang berpengaruh terhadap keterampilan seseorang itu seperti: kelentukan, kecepatan, dan koordinasi mata-kepala.

Kelentukan dapat membantu atlet untuk mengembangkan gerakan-gerakan yang diinginkannya dan mencegah terjadinya cedera. Menurut Arsil (2008) kelentukan adalah kemampuan menggerakkan persendian dan otot pada keseluruhan ruang geraknya. Sedangkan Jonath/Krempel dalam Syafruddin (2011) mengatakan "Kelentukan (flexibility) merupakan kemampuan tubuh untuk melakukan latihan-latihan dengan amplitudo gerakan yang besar atau luas". Untuk meningkatkan kelentukan tubuh dapat dilakukan dalam bentuk latihan yang sudah terprogram dan berkesinambungan seperti latihan peregangan dinamis dengan latihan membungkukkan badan sambil memutar bahu dan latihan peregangan statis dengan cara penguluran otot dalam sendi sejauh mungkin seperti duduk dengan meraih ujung jari kaki. Untuk itu pelatih harus menyusun program yang baik dan benar sesuai dengan kebutuhan dan tujuan yang diingin dicapai. Apabila program yang dibuat benar, maka kelentukan seorang atlet akan bagus. Dan ini akan berimbas pada peningkatan prestasinya. Untuk menyundul bola, kelentukan yang perlu dilatih adalah kelentukan persendian tubuh, kelentukan togok dan kelentukan otot leher. Ini mendakan seseorang tidak akan bisa menyundul bola dengan baik tanpa didukung oleh kemampuan kelentukan, terutama kelentukan otot togok, karena kelentukan diperlukan untuk mengoptimalkan pergerakan saat pelaksanaan menyundul bola.

Selanjutnya, kondisi fisik yang berpengaruh terhadap Kemampuan Menyundul Bola Posisi Berdiri adalah koordinasi. Bob Davis, et al (2007) menyatakan bahwa koordinasi adalah kemampuan untuk menampilkan gerak yang halus dan tepat, seringkali melibatkan penggunaan perasaan dan dihubungkan dengan serangkaian kontraksi otot yang mempengaruhi gabungan anggota tubuh dan posisi tubuh. Sedangkan Harrow (2002) menyatakan bahwa koordinasi termasuk aktifitas yang terdiri dari dua atau lebih kemampuan dan pola gerak. Koordinasi matakepala adalah kemampuan seseorang dalam melakukan ketepatan dan kesempurnaan gerakan otot dari satu pola gerak ke pola gerak berikutnya dengan efisien. Dengan komponen koordinasi mata-kepala, seorang pemain sepakbola akan dapat melakukan menyundul bola dengan baik dan cepat, karena pemain tersebut akan dapat menggabungkan beberapa elemen gerak menyundul bola menjadi satu pola gerak menyundul bola yang halus, efisien dan harmonis. Dalam pelaksanaan menyundul bola, koordinasi seluruh tubuh harus terlaksana dengan baik, terutama koordinasi antara mata dan kaki. Dimana mata akan melihat arah, sedangkan kaki akan menyentuh bola atau menentukan langkah, sehingga kemampuan menyundul bola bisa tercapai sesuai dengan apa yang diharapkan.

Selain teknik dan kondisi fisik aspek psikologis yang juga sering mempengaruhi pemain sepakbola adalah faktor percaya diri. Tanpa memiliki penuh percaya diri, atlet tidak akan dapat mencapai prestasi, karena ada saling hubungan antara motif berprestasi dan percaya diri. Dalam 
upaya pencapaian prestasi tinggi, keadaan fisik maupun mental atlet harus dalam kondisi puncak. Sesuai dengan pendapat Sudibyo Setyobroto (2002) yang menegaskan bahwa prestasi yang tinggi hanya dapat dicapai dengan mobilitas total seluruh energi dalam hal ini peranan kesiapan mental akan ikut menentukan. Percaya diri atau self-confidence merupakan modal utama seorang atlet untuk dapat maju, karena pencapaian prestasi yang tinggi dan pemecahan rekor atlet itu sendiri harus dimulai dengan percaya bahwa atlet dapat dan sanggup melampaui prestasi yang pernah dicapainya. Tanpa memiliki penuh rasa percaya diri, atlet tidak akan dapat mencapai prestasi, karena ada saling hubungan antara motif berprestasi dan percaya diri. Orang yang memiliki kepercayaan diri rendah cenderung selalu memiliki perasaan negatif terhadap dirinya, keyakinan terhadap dirinya lemah, dan pengetahuan yang kurang akurat tentang kapasitas yang dimilikinnya (Sulistiadinata \& Purbangkara, 2020). Percaya diri biasanya erat dengan hubungan emotional security. Makin mantap kepercayaan pada diri sendiri, makin mantap pula emotional security-nya. Percaya diri yang tinggi akan meningkatkan kualitas permainan, terutama saat menyundul bola.

Berdasarkan pemaparan di atas, maka penelitian ini bertujuan untuk mengetahui seberapa besarnya hubungan rasa percaya diri, kelentukan togok dan koordinasi mata-kepala dengan Kemampuan Menyundul Bola Posisi Berdiri.

\section{METODE}

Penelitian ini menggunakan metode deskriptif dengan pendekatan korelasional yaitu menghubungkan satu variabel dengan variabel lain untuk memahami suatu fenomena dengan cara menentukan tingkat atau derajat hubungan di antara variabel-variabel tersebut. Variabel yang digunakan untuk mengukur hubungan antara variabel-variabel bebas yaitu: percaya diri $\left(\mathrm{X}_{1}\right)$ kelentukan togok $\left(\mathrm{X}_{2}\right)$ dan koordinasi mata-kepala sebagai variabel $\left(\mathrm{X}_{3}\right)$ dengan Kemampuan Menyundul Bola Posisi Berdiri pada atlet sepakbola klub ANDECI Junior sebagai (Y).

Populasi penelitian adalah atlet sepakbola klub ANDECI Juior yang berjumlah 20 orang. Pengambilan sampelnya dilakukan dengan menggunakan teknik sampling jenuh (sensus), yang berjumlah 20 orang. Data yang dikumpulkan dalam penelitian ini meliputi: data angket untuk tes percaya diri, data tes kelentukan togok, data tes koordinasi mata-kepala, dan data tes menyundul bola.

Adapun instrumen tes kelentukan togok menggunakan tes flexiometer (Widiastuti, 2011), tes koordinasi mata-kepala menggunakan tes koordinasi Mata-kepala (Winarno, 2006), tes menyundul bola menggunakan tes teknik Menyundul Bola (Penulis, 2016), dan tes percaya diri menggunakan angket. 
Analisis ini meliputi pengujian persyaratan analisis dan pengujian hipotesis penelitian. Pengujian persyaratan analisis menggunakan uji normalitas dengan Kolmogorov-Smirnov pada SPSS 17 for Windows. Uji hipotesis dengan teknik regresi dan korelasi. Data yang diperoleh diolah dengan teknik korelasi product moment.

\section{HASIL PENELITIAN}

Uji normalitas dimaksud agar distribusi sampling dari galat taksiran sampel mendekati normalitas populasi. Berikut ini ditampilkan tabel output SPSS uji normalitas dari masing-masing variabel.

Tabel 1. Uji Normalitas Dengan Kolmogorov-Smirnov Test

\begin{tabular}{cccc}
\hline Variabel & Kolmogorov Smirnov & Asymp.sig. & Keterangan \\
\hline Percaya Diri $\left(\mathrm{X}_{1}\right)$ & 0.89 & & Normal \\
Kelentukan Togok $\left(\mathrm{X}_{2}\right)$ & 0.38 & 0.05 & Normal \\
Koordinasi Mata-kepala $\left(\mathrm{X}_{3}\right)$ & 0.06 & & Normal \\
Menyundul Bola $\left(\mathrm{X}_{4}\right)$ & 0.81 & & Normal \\
\hline
\end{tabular}

Berdasarkan Tabel di atas dapat dilihat bahwa untuk variabel Percaya Diri $\left(\mathrm{X}_{1}\right)$ diperoleh hasil sebesar 0.89, Kelentukan Togok $\left(\mathrm{X}_{2}\right)$ sebesar 0.38, Koordinasi Mata-kepala $\left(\mathrm{X}_{3}\right)$ sebesar 0.06, dan Menyundul Bola $\left(\mathrm{X}_{4}\right)$ sebesar 0.81, dengan Asymp.sig. 0.05, maka dapat disimpulkan bahwa semua variabel berdistribusi normal.

\section{Hubungan antara Rasa Percaya Diri $\left(X_{1}\right)$ dengan Kemampuan Menyundul Bola Posisi Berdiri (Y)}

Koefisien korelasi tersebut harus diuji terlebih dahulu mengenai keberartian (positif) sebelum digunakan untuk mengambil suatu kesimpulan dengan mencari $t_{\text {hitung. Adapun hasil }}$ Pengujian Hipotesis Koefisien Korelasi Antara $\mathrm{X}_{1}$ dengan $\mathrm{Y}$ tersaji pada tabel 3 berikut ini.

Tabel 2. Hasil Pengujian Hipotesis Koefisien Korelasi Antara $\mathrm{X}_{1}$ dengan Y

\begin{tabular}{ccccc}
\hline Korelasi antara & Koefisien Korelasi $(\mathrm{r})$ & thitung & $\mathrm{t}_{\text {tabel }} \alpha 0,05$ & Kriteria korelasi \\
\hline $\mathrm{X}_{1}$ dan $\mathrm{Y}$ & 0.732 & 4.615 & 1,734 & Sangat tinggi \\
\hline
\end{tabular}

Berdasarkan tabel di atas terlihat $r_{\text {hitung }}=0.736$ menyatakan tingkat hubungan antara rasa percaya diri dengan Kemampuan Menyundul Bola Posisi Berdiri adalah sangat tinggi, dimana nilai $t_{\text {hitung }}=4.615>t_{\text {tabel }}=1.734$. Jadi, Ho ditolak yang berarti ada hubungan yang positif antara rasa percaya diri $\left(\mathrm{X}_{1}\right)$ dengan Kemampuan Menyundul Bola Posisi Berdiri (Y). Besarnya kontribusi (sumbangan) rasa percaya diri terhadap Kemampuan Menyundul Bola Posisi Berdiri 
dapatditentukan dengan koefisien determinasi $\mathrm{r}^{2} \times 100 \%=0.7362 \times 100 \%=54,17 \%$ Artinya, dengan memiliki rasa percaya diri yang baik maka keterampilan menyundu bola akan meningkat.

\section{Hubungan antara Kelentukan togok $\left(\mathrm{X}_{2}\right)$ dengan Kemampuan Menyundul Bola Posisi Berdiri (Y)}

Koefisien korelasi tersebut harus diuji terlebih dahulu mengenai keberartian (positif)

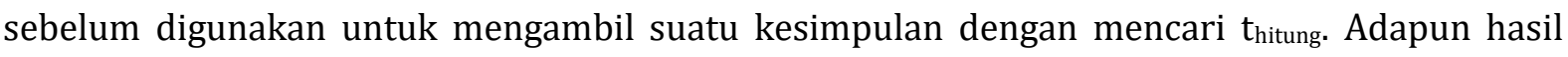
Pengujian Hipotesis Koefisien Korelasi Antara $\mathrm{X}_{2}$ dengan $\mathrm{Y}$ tersaji pada tabel 4 berikut ini.

Tabel 3. Hasil Pengujian Hipotesis Koefisien Korelasi Antara $\mathrm{X}_{2}$ dengan $\mathrm{Y}$

\begin{tabular}{ccccc}
\hline Korelasi antara & Koefisien Korelasi (r) & thitung & $t_{\text {tabel }} \alpha 0,05$ & $\begin{array}{c}\text { Kriteria } \\
\text { Korelasi }\end{array}$ \\
\hline $\mathrm{X}_{2}$ dan $\mathrm{Y}$ & 0.880 & 7.877 & 1,734 & Sangat tinggi \\
\hline
\end{tabular}

Berdasarkan tabel di atas terlihat $r_{\text {hitung }}=0.880$ menyatakan tingkat hubungan antara kelentukan togok dengan Kemampuan Menyundul Bola Posisi Berdiri adalah sangat tinggi, dimana nilai $t_{\text {hitung }}=7.877>t_{\text {tabel }}=1,734$. Jadi, Ho ditolak yang berarti ada hubungan yang positif antara kelentukan togok $\left(\mathrm{X}_{2}\right)$ dengan Kemampuan Menyundul Bola Posisi Berdiri ( $\mathrm{Y}$ ). Besarnya kontribusi (sumbangan) kelentukan togok terhadap Kemampuan Menyundul Bola Posisi Berdiri dapat ditentukan dengan koefisien determinasi $r^{2}$ x 100\% $=0.880^{2}$ x 100\% $=77.44 \%$. Artinya, dengan memiliki kemampuan kelentukan togok yang baik maka Kemampuan Menyundul Bola Posisi Berdiri akan meningkat. Hal ini disebabkan karena sepakbola merupakan olahraga open skill yang menuntut setiap atlet untuk dapat bergerak dengan cepat dan lincah serta dapat melakukan eksekusi gerakan pada timing yang tepat. Sehingga dengan melakukan latihan-latihan kelentukan maka keterampilan menggring bola akan semakin baik.

\section{Hubungan antara Koordinasi Mata-kepala $\left(X_{3}\right)$ dengan Kemampuan Menyundul Bola Posisi Berdiri (Y)}

Koefisien korelasi tersebut harus diuji terlebih dahulu mengenai keberartian (positif)

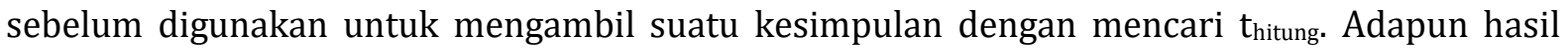
Pengujian Hipotesis Koefisien Korelasi Antara $\mathrm{X}_{3}$ dengan $\mathrm{Y}$ tersaji pada tabel 5 berikut ini. 
Tabel 4. Hasil Pengujian Hipotesis Koefisien Korelasi Antara $\mathrm{X}_{3}$ dengan $\mathrm{Y}$

\begin{tabular}{ccccc}
\hline Korelasi antara & Koefisien Korelasi ( $r)$ & thitung & $t_{\text {tabel }} \alpha 0,05$ & $\begin{array}{c}\text { Kriteria } \\
\text { Korelasi }\end{array}$ \\
\hline $\mathrm{X}_{3}$ dan $\mathrm{Y}$ & 0.764 & 5.078 & 1,734 & Sangat tinggi \\
\hline
\end{tabular}

Berdasarkan tabel di atas terlihat $\mathrm{r}_{\text {hitung }}=0.767$ menyatakan tingkat hubungan antara koordinasi mata-kepala dengan Kemampuan Menyundul Bola Posisi Berdiri adalah sangat tinggi. dimana nilai $t_{\text {hitung }}=5.078>t_{\text {tabel }}=1,734$. Jadi, Ho ditolak yang berarti ada hubungan yang positif antara koordinasi mata-kepala $\left(\mathrm{X}_{3}\right)$ dengan Kemampuan Menyundul Bola Posisi Berdiri ( $\mathrm{Y}$ ). Besarnya kontribusi (sumbangan) koordinasi mata-kepala terhadap Kemampuan Menyundul Bola Posisi Berdiri dapat ditentukan dengan koefisien determinasi $r^{2} \times 100 \%=0,767^{2} \times 100 \%=$ 58.83\%. Artinya, dengan memiliki kemampuan koordinasi mata-kepala yang baik maka Kemampuan Menyundul Bola Posisi Berdiri akan meningkat.

\section{Hubungan antara Rasa Percaya Diri $\left(X_{1}\right)$, Kelentukan Togok $\left(X_{2}\right)$ dan Koordinasi Mata- kepala $\left(\mathrm{X}_{3}\right)$ dengan Kemampuan Menyundul Bola Posisi Berdiri (Y)}

Koefisien korelasi tersebut harus diuji terlebih dahulu mengenai keberartian (positif) sebelum digunakan untuk mengambil suatu kesimpulan dengan mencari $\mathrm{F}_{\text {hitung. Adapun hasil }}$ Pengujian Hipotesis Koefisien Korelasi Antara X1, $\mathrm{X}_{2}, \mathrm{X}_{3}$, dengan $\mathrm{Y}$ tersaji pada tabel 6 berikut ini.

Tabel 5. Hasil Pengujian Hipotesis Koefisien Korelasi Antara $\mathrm{X}_{1}, \mathrm{X}_{2}, \mathrm{X}_{3}$ dengan $\mathrm{Y}$

\begin{tabular}{ccccc}
\hline Korelasi antara & Koefisien Korelasi $(\mathrm{r})$ & Fhitung & $\mathrm{F}_{\text {tabel }} \alpha 0,05$ & $\begin{array}{c}\text { Kriteria } \\
\text { Korelasi }\end{array}$ \\
\hline $\mathrm{X}_{1}, \mathrm{X}_{2}, \mathrm{X}_{3}$ dengan $\mathrm{Y}$ & 0.890 & 20.439 & 5,12 & Sangat tinggi \\
\hline
\end{tabular}

Berdasarkan tabel 6 terlihat $\mathrm{r}_{\text {hitung }}=0.890$ menyatakan tingkat hubungan antara rasa percaya diri $\left(\mathrm{X}_{1}\right)$, kelentukan togok $\left(\mathrm{X}_{2}\right)$ dan koordinasi mata-kepala $\left(\mathrm{X}_{3}\right)$ dengan Kemampuan Menyundul Bola Posisi Berdiri (Y) adalah sangat tinggi, dimana nilai $F_{\text {hitung }}=20.439>F_{\text {tabel }}=5,12$ pada taraf positifsi $\alpha 0,05$. Jadi, Ho ditolak yang berarti ada hubungan yang positif antara rasa percaya diri $\left(\mathrm{X}_{1}\right)$, kelentukan togok $\left(\mathrm{X}_{2}\right)$ dan koordinasi mata-kepala $\left(\mathrm{X}_{3}\right)$ dengan Kemampuan Menyundul Bola Posisi Berdiri (Y). Besarnya kontribusi (sumbangan) rasa percaya diri, kelentukan togok, dan koordinasi mata-kepala dengan keterampilan menyundul bola dapat ditentukan dengan koefisien determinasi $\mathrm{r}^{2}$ x 100\% $=0.890^{2} \times 100 \%=79.21$. Artinya, dengan memiliki kemampuan rasa percaya diri, kelentukan togok dan koordinasi mata-kepala yang baik 
maka seorang atlet akan mampu melakukan Kemampuan Menyundul Bola Posisi Berdiri dengan sempurna.

\section{KESIMPULAN}

Berdasarkan hasil penelitian yang telah diuraikan di atas, dapat disimpulkan sebagai berikut: (1) terdapat hubungan yang signifikan antara rasa percaya diri dengan Kemampuan Menyundul Bola Posisi Berdiri, (2) terdapat hubungan yang signifikan antara kelentukan togok dengan Kemampuan Menyundul Bola Posisi Berdiri, (3) terdapat hubungan yang signifikan antara koordinasi mata-kepala dengan Kemampuan Menyundul Bola Posisi Berdiri, dan (4) terdapat hubungan yang signifikan secara bersama-sama antara rasa percaya diri, kelentukan togok, dan koordinasi mata-kepala dengan Kemampuan Menyundul Bola Posisi Berdiri.

\section{DAFTAR PUSTAKA}

Bob Davis, et al. 1997. Phisycal Education and the Study of Sport, London: Mosby International.

Harrow. 1972, Anita J. A Taxonomy of the Psychomotor Domain, New York: Longman Inc.

Sulistiadinata, H., \& Purbangkara, T. (2020). Hubungan Kekuatan Otot Lengan, Koordinasi Mata Tangan, Dan Rasa Percayadiri Dengan Keterampilan Smash Pada Permainan Bola Voli. Jurnal Master Penjas Dan Olahraga, 1(April), 32-38. Retrieved from http://jmpo.stkippasundan.ac.id/index.php/jmpo/article/view/5/4

Sudibyo Setyobroto. 2002. Psikologi Olahraga, Jakarta: PT. Anem Kosong Anem.

Sucipto, dkk. 2000, Sucipto, Sepakbola. Jakarta: Departemen Pendidikan Nasional.

Syafruddin. 2011. Ilmu Kepelatihan Olahraga Teori dan Aplikasinya dalam PembinaanOlahraga, Padang: Fakultas Ilmu Keolahragaan Universitas Negeri Padang.

Widiastuti. 2011. Tes dan pengukuran olahraga. Jakarta: PT Bumi Timur Jaya.

Winarno. 2006. Perspektif pendidikan jasmani dan olahraga. Malang: Laboratorium Jurusan Ilmu Keolahragaan Fakultas Ilmu pendidikan Universitas Negeri Malang.

Valentino, R. F., \& Iskandar, M. (2020). Identifikasi Minat Siswa Pada Ekstrakurikuler Sepak Bola. Jurnal Master Penjas Dan Olahraga, 1(April), 47-54. Retrieved from http://jmpo.stkippasundan.ac.id/index.php/jmpo/article/view/7/6 